Article

\title{
The Political Debate on Climate Change in Italy: A Discourse Network Analysis
}

\author{
Stefano Ghinoi * and Bodo Steiner \\ Department of Economics and Management, University of Helsinki, 00014 Helsinki, Finland; \\ E-Mails: stefano.ghinoi@helsinki.fi (S.G.), bodo.steiner@helsinki.fi (B.S.) \\ * Corresponding author
}

Submitted: 24 October 2019 | Accepted: 12 February 2020 | Published: 2 June 2020

\begin{abstract}
Climate change is considered by policymakers as one of the most pressing global issues of our time. International institutions and national governments are, to varying degrees, committed to tackling climate change, but it has only been possible to define a shared system of collective goals across countries through the 2015 United Nations Climate Change Conference in Paris (COP21). A growing interest in climate change policy has been present in the Italian political debate, yet we have little evidence regarding the nature of related climate change debates across Italian policymakers. By using discourse network analysis (DNA) to investigate Italian policymakers' discourses in the Chamber of Deputies during the 17th Italian Legislature (2013-2018), this study shows that debates on climate change-related strategies are largely unpolarized, except for certain issues, and that coalitions emerge over time around core strategies. Groups of policymakers with similar policy beliefs emerge independently from their political affiliations. Our analysis is thus the first to apply DNA to provide empirical evidence of the convergence across Italian policymakers and the potential for the bridging of political discourses on climate change.
\end{abstract}

\section{Keywords}

climate change; discourse network analysis; Italy; Paris COP21 Agreement; policy coalitions

\section{Issue}

This article is part of the issue "Policy Debates and Discourse Network Analysis" edited by Philip Leifeld (University of Essex, UK).

(C) 2020 by the authors; licensee Cogitatio (Lisbon, Portugal). This article is licensed under a Creative Commons Attribution 4.0 International License (CC BY).

\section{Introduction}

The first two decades of the 21st century have seen national governments become increasingly concerned with climate change issues (Pearce, Brown, Nerlich, \& Koteyko, 2015). However, policymakers' approaches to dealing with climate change are vague (Biesbroek et al., 2010; Keohane \& Oppenheimer, 2016; Kukkonen et al., 2018) or even reductive concerning its causes, when we consider, for example, greenhouse gas emissions (GHG; Dunlap \& McCright, 2011). Policymakers are challenged with political conflicts when defining international and national strategies for addressing climate change. The annual United Nations Conferences of the Parties (COP) aim to reduce these conflicts at an international level.
However, their effectiveness had been limited in the past by their intrinsic weaknesses, that is until the 2015 United Nations Climate Change Conference (COP21) and the Paris Agreement, which defined collective and binding goals (Victor, 2016). This international approach influenced political debate within countries, contributing to the definition of climate change issues and associated strategies for achieving the Paris targets (Kukkonen, Ylä-Anttila, \& Broadbent, 2017).

Previous country-level evidence suggests that climate change is a divisive topic (Kukkonen et al., 2017, 2018) and that one of the main factors influencing policymakers' climate change opinion is their political affiliation (Rossen, Dunlop, \& Lawrence, 2015). However, recent studies from across Europe (France, Germany, 
the Netherlands, Poland, Spain, Ireland) demonstrate that policymakers belonging to different political groups can share similar positions on climate change (Hess \& Renner, 2019; Little, 2017; Marcinkiewicz \& Tosun, 2015). Yet, to date, there is little evidence of this having occurred in the third-largest national economy in the Eurozone, Italy.

Our work contributes to the discussion on the nature of coalitions and their relations to political realignment (Kukkonen et al., 2018). Further, this article contributes to the empirical literature on climate change political debates in two ways. First, we focus on the case of Italy, from where we have thus far no evidence on the nature of climate change discourses across policymakers. Second, we use a different empirical basis compared to previous work, by analysing the exact recorded wordings from Italian debates from within the Italian Chamber of Deputies during the 17th Legislature (2013-2018).

\section{Background}

\subsection{Climate Change, Policymaking and the Political Debate}

According to the Intergovernmental Panel on Climate Change (IPCC, 2018), our world has entered a new geological epoch, the Anthropocene. The effects of human activities on the Earth's Systems are unprecedentedly significant, causing a constant increase of the GHG and transforming the biosphere. These changes have already produced an intensification of extreme climate events (Diffenbaugh et al., 2017), which negatively impact human activities and ecosystems.

Since the 1980s, two main strategies have been employed by national and international organizations to address the negative effects of climate change: mitigation (e.g., reducing GHG) and adaptation (e.g., actions for addressing the impacts of climate change and reducing vulnerability; Gupta, 2010). During the 1990s, international and national policies initially focused their attention on mitigation, but later it became clear that adaptation measures were also necessary to avoid further negative effects (IPCC, 2018). Faced with these climate change-related effects, National governments put efforts into the creation of international treaties. In the last decades, the annual COP have driven the international debate on climate change; however, this strategy has proven to be ineffective over time, since a universal agreement has always been difficult to achieve (Victor, 2016). Nonetheless, the Paris Agreement defined during the COP21 is considered a success by some observers (Bang, Hovi, \& Skodvin, 2016). This agreement includes two collective goals, keeping the rise in average global temperature below $2^{\circ} \mathrm{C}$ (striving to limit the increase below $1.5^{\circ} \mathrm{C}$ ) and achieving worldwide carbon neutrality between 2050 and 2100, while the strength of the agreement rests on the fact that it "lets countries set their own commitments" (Victor, 2016, p. 135).
As pointed out by Carter, Ladrech, and Little (2014) and Kukkonen et al. (2018), international treaties influence the national policy-making process for establishing environmental targets and strategies. Nevertheless, national policies are developed and implemented by national policymakers, whose opinions on this topic can be divisive (Kukkonen et al., 2017). Among the different elements that influence policymakers' perspectives on climate change, political ideology has a prominent role: In Western countries, right-wing parties are more sceptical about the existence of the climate change phenomena and its impact on the environment, while the political left is more responsive to the warnings from the scientific world (Rossen et al., 2015). However, recent studies show how the convergence of rival political parties on climate change-related issues is increasing, especially in European countries. Marcinkiewicz and Tosun (2015) find that Polish deputies, regardless of their political membership, do not consider climate change as an area of political competition, hence they do not show marked differences in their opinion on this topic. Little (2017) illustrates that the main Irish parties presented a shared consensus on climate policies during the 2016 elections. Consistent with these studies, Hess and Renner (2019) find convergences concerning energytransition policies between conservative parties and farright parties in six European countries (France, Germany, the Netherlands, Poland, Spain, and the UK). Recent evidence from European parliament discourses on the politics of climate change provides further evidence for convergence, since it suggests a low level of external politicization, as indicated by low party group polarization, internalization of political conflict at the committee level, and compromise-building between issue dimensions (Wendler, 2019).

Political debates can be useful to understand policymakers' behaviour, which directly influences the political process (Schmidt, 2008). These debates also allow for greater understanding of coalition formation and the prevalence of certain viewpoints over others (Leifeld \& Brandenberger, 2019). Furthermore, the formation of coalitions is, within their institutional frameworks, part of the political leadership choices that interact to formulate policy lines and to shape trajectories of economic development and international relations (Oppermann, Kaarbo, \& Brummer, 2017). As part of creating such policy lines, coalition formation can shape political re-alignment dynamically, in policy cycles (Howlett, McConnell, \& Perl, 2017), and contest the most appropriate policy process (Mukherjee \& Howlett, 2015). Such dynamics of policy processes and dueling coalitions of political actors have been explained with the Advocacy Coalition Framework model of Sabatier (1991). Relative to the Advocacy Coalition Framework, other policy frameworks that also explain coalition formation appear more simplistic, as they view policy processes as consisting of sequential, cyclical phases or 'stages' of governmental problem-solving; this has led Howlett et al. 
(2017) to reconcile the conceptual pillars of the multiplestage and cycle models with the Advocacy Coalition Framework, to better model competing coalitions of interests within a policy subsystem.

The role of political coalitions for the sustainability transition has received significant attention (Haukkala, 2018; Hess, 2014). The work of Haukkala (2018) describes how the Finnish green-transition advocacy coalition manages the different points of view expressed by its groups: Different perspectives lead to different strategies, which could affect the coalition's structure. By investigating the role of incumbent regime coalitions, grassroots coalitions, and the countervailing industrial power in the US, Hess (2014) finds that non-state actors are particularly relevant in supporting political campaigns and driving political coalitions' success. The environmental discourse has been further studied through the focus on discourse coalitions in the case of the fracking debate in the UK and the US (Bomberg, 2017; Metze \& Dodge, 2016), as well as regarding the polarized discourses around environmental conflict in Australia (Lucas \& Warman, 2018), and the construction of urban megaprojects in Germany (Nagel \& Satoh, 2019).

\subsection{The Italian Context}

In one of the first studies dedicated to Italian climate change policy, Marchetti (1996, p. 299) points out that this topic is influenced "by traditional policy styles and the outlooks of key policymakers." Environmental issues have had a marginal role in Italian politics, making Italy one of the last Western countries to enter into the environmental policy arena (Westerhoff, 2010). The first climate policy introduced by the Italian Government was related to the ratification of the United Nations Framework Convention on Climate Change in 1994; the Guidelines for National Policies and Measures regarding the Reduction of GHG Emissions were introduced in 1998, while the first National Climate Change Conference was organized by the Ministry of the Environment in 2007 (Westerhoff, 2010). Since 2010, Italy has concentrated on the implementation of national climate change adaptation strategies (Pasimeni, Valente, Zurlini, \& Petrosillo, 2019), but, on the other hand, it has "not included a line of policy oriented to enhance climate initiatives at the local level, nor has it launched collaborative arenas where national climate action could be discussed" (De Gregorio Hurtado et al., 2014, p. 80).

Climate change was not the main issue in the manifestos of most of the political parties represented in the Italian Parliament (De Blasio \& Sorice, 2013). Traditionally, most of the Italian parties were not particularly environment-focused, except for the Green Party; center-left parties have always had an industrialist culture related to their communist tradition, while centerright parties were against climate change legislation because, in their opinion, it would favor bureaucratic dirigisme (Carter et al., 2014). Historically, center-right parties have been against climate change initiatives, as in the case of the 2008 European legislative proposal on energy and climate change, which was contested by the Berlusconi's government because it would have damaged Italian industries (Carbone, 2009). This situation has changed in recent years, as increasing coverage of extreme natural events by national media (Pasquaré \& Oppizzi, 2012) has raised climate change awareness within the Italian population (European Investment Bank, 2019), creating a demand for concrete action by policymakers.

Subsequently, new political parties emerged, while traditional parties tried to reorient their political manifesto. The Five Star Movement was created as an antiestablishment party in 2005, and one of its main objectives is the protection of the environment. As illustrated by Lanzone and Woods (2015, p. 57), this party "emerged as a constellation of local issues galvanized around a populist thematic of politics and political representation being about the real people." Its political representatives carry out a communicative strategy where the Movement is portrayed as the only political party interested in the protection of the environment, with the others being portrayed as having contributed to environmental degradation. In reaction to these allegations and to build consensus, political leaders from traditional parties re-framed their climate change positions, pointing out the importance of this topic in the political agenda (Biscotti \& D'Amico, 2016). In particular, center and center-left parties (which governed in the 17th Italian Legislature 2013-2018) put effort into the preparation of COP21 (Sartori, 2016), influencing the Italian policymaking process. Furthermore, the ratification of the Paris Agreement and the implementation of the National Plan for Energy and Climate (Piano Nazionale Integrato per l'Energia e il Cima) influenced the political debate after COP21. However, we lack empirical evidence and analyses on the Italian political context in which discourse coalitions developed regarding climate change. Since these changes (growing interest in climate change and the influence exerted by the COP21) strongly influenced the Italian political arena and Italian parties, our research question is the following: Which discourse coalitions emerged from the political debate on climate change in Italy?

\section{Discourse Network Analysis: Methodology and Data}

Discourse coalitions in the political arena depict the political alliances which form around the issues under debate (Fisher, Leifeld, \& Iwaki, 2013), since, as pointed out by Leifeld and Haunss (2012, p. 383), "discourses precondition political action." Discourse network analysis (DNA) is a method that facilitates the examination and the visualization of these coalitions by integrating qualitative Content Analysis and quantitative tools derived from Social Network Analysis (Fisher et al., 2013; Fisher \& Leifeld, 2019; Leifeld, 2017). It allows the ac- 
tors involved in political debates and the coalitions created around specific issues to be mapped and it can be employed to analyse any type of political issue, such as agricultural (Ghinoi, Wesz, \& Piras, 2018), environmental (Fisher et al., 2013; Kukkonen et al., 2017), food (Fergie, Leifeld, Hawkins, \& Hilton, 2019), immigration (Wallaschek, 2019), and property rights issues (Leifeld \& Haunss, 2012).

DNA is applied to statements made by the actors operating in the context object of analysis. A statement is "a text portion where an actor reveals his or her policy beliefs or preferences in the text" (Fisher \& Leifeld, 2019, p. 475) on a certain concept. Therefore, actors, concepts, and the agreement relationship between actors and concepts are the fundamental elements of the analysis. There are two types of discourse networks: twomode and one-mode networks. The former includes two types of nodes, actors and concepts: An actor is linked to a concept if they have expressed a statement about it, and the links (i.e., network ties) can have a positive characterization (if the actor agrees on that concept) or a negative characterization (if the actor does not agree on it). One-mode networks are made by actors, where two actors are linked if they both express a statement on the same concept; the more they make statements on multiple concepts, the thicker the network tie between such actors becomes. Two aggregation methods are used to create one-mode networks: one based on congruence, where a tie is established if two actors both agree on a concept or if they both do not agree; and another based on the presence of conflict, where a tie is established if one actor agrees on a concept and another actor does not agree (Leifeld, 2017). In our work, statements were collected from the verbatim reports of the Chamber of Deputies proceedings for the 17th Italian parliamentary term (2013-2018), which are available online (around 900 verbatim reports are available on the website of the Chamber of Deputies). During that period, Italy had three different Governments supported by a coalition of center and center-left parties (with three Prime Ministers: Enrico Letta, 2013-2014; Matteo Renzi, 2014-2016; and Paolo Gentiloni, 2016-2018).

Since climate change is a multifaceted issue (Wendler, 2019) that entails a broad variety of challenges and potential solutions for mitigation or adaptation, our data collection does not merely focus on who expresses a statement on the existence of climate change, but also on which solutions are proposed to mitigate its effects, or why certain strategies should (or should not) be implemented. We use the existing literature to reference and classify climate change strategies into five main categories: agriculture; energy; industry, innovation, and economy; land planning and management; and migration (Table 1). As illustrated in the IPCC report (2018), agriculture is particularly sensitive to climate change and a number of strategies can be developed to reduce GHG and adapting to climate change. In particular, the IPCC focuses on increasing food security, providing education to farmers, and supporting the adoption of Genetically Modified Organisms (GMOs), i.e., solutions related to the innovativeness of the agricultural sector. In addition to these strategies, policymakers are also focused on strategies for supporting (or not) the livestock sector in order to reduce its emissions (Gerber et al., 2013b). The energy sector directly impacts the volume of emissions and it is strictly related to climate change. According to the IPCC report (2018), several energy strategies influence, positively or negatively, the production of GHG: coal extraction; support of renewable energies; oil and gas drilling; production and use of nuclear energy; carbon capture and storage. In order to reduce GHG, energy efficiency should be increased and a waste management system for producing energy from composting waste must be implemented (Biala, 2011; IPCC, 2018); moreover, regarding waste management, another issue concerns the development of incinerators and their impact in terms of GHG (European Commission, 2001). Industrial and economic strategies for challenging climate change are particularly extensive. The UN (2015) support economic strategies which aim to introduce pollution taxes and reduce tax advantages for polluting companies, thus promoting the green economy and green jobs, and supporting technological innovation for sustainability. The IPCC (2018) recommends strengthening the public transport system and investing in the formation of sustainability professionals for business activities. In addition to the proposals of international organizations, new economic paradigms have arisen in recent decades: the degrowth paradigm and the circular economy paradigm. The former (Latouche, 2010) introduces the idea that infinite growth is un-realistic and un-sustainable, therefore degrowth is necessary to reduce GHG and tackle climate change. The latter is based on the $3 R^{\prime}$ s concept (reduce, reuse, and recycle) and the design of business strategies to close resource loops and lower the impact of human activities on the environment (Circle Economy, 2019). Finally, the IPCC report (2018) highlights that those communities dependent on agriculture will be negatively influenced by the global temperature rise, which will increase migration flows from Southern countries and vulnerable areas, and the International Organization for Migration (2008) points out the importance of distinguishing between refugees, migrants, climate refugees, and climate migrants. This issue is particularly relevant in the Italian context: Italy is the first country of arrival (together with Greece and Spain) for individuals coming from the Middle East and African countries (Locchi, 2014), therefore it needs a strategy for handling migrants and refugees.

Since the Paris Agreement was discussed and ratified by the Italian Chamber of Deputies on the 19th of October, 2016, the time window of our analysis is based around this date. We analyzed the political debates by focusing on two discourse networks, pre- and post-October 2016, in order to distinguish between those which occurred before the ratification and those which occurred since then as we assume that deputies modified their ex- 
pectations (in terms of environmental targets to pursue) before and after that event. The data coding and management was carried out via the Discourse Network Analyzer software (Leifeld, 2010). For network visualization and analysis, we use Ucinet (Borgatti, Everett, \& Freeman, 2002) and the visone software. Once uploaded the verbatim reports, the text parts dedicated to climate change were extrapolated by using the following keywords: 'climate change' (in English), 'climate' (in English), 'clima' (in Italian), 'cambiamento climatico' (in Italian), and 'cambiamenti climatici' (in Italian). Then, the policy beliefs of the members of the Chamber of Deputies appearing in the selected text parts were manually coded. In total, we mapped 121 deputies (out of 630) who made at least one statement on a climate change-related strategy. From the verbatim reports, we retained 348 statements that: 1) Encompassed the relevant keywords; and 2) were coherent with the strategies illustrated in Table 1. Most of these statements (around 80\%) were dedicated to the discussion of one single strategy, while the $6 \%$ was dedicated to the discussion of three or more strategies. The most debated strategies were those focused on land planning and management, renewable energies, and oil drilling activities. Following Fisher and Leifeld (2019), statements pre- and post-October 2016 were first transformed into actor-by-strategy matrices, which are the equivalent of two-mode networks, where a tie has a positive characterization when a deputy agrees on a certain strategy (e.g., if a deputy supports oil drilling activities) and a negative characterization otherwise (e.g., if a deputy does not support oil drilling activities). Duplicate statements were ignored in the matrix creation. Then, the two-mode networks were converted into one-mode networks, by using the congruence network approach and the conflict network approach (Leifeld, 2017). Using the congruence network approach, deputies with similar beliefs on a certain strategy, both in a positive in a negative way, are linked together with edges that are proportionally weighted to the number of shared beliefs; with the conflict network approach, deputies are linked if they have an opposite view on a certain strategy. In the creation of these networks, we used the normalization method of the edge weights illustrated by Leifeld (2017), in order to remove potential problems due to core-periphery structures. Moreover, we also created additional networks where 'weak' edges (edges with a

Table 1. Strategies related to climate change.

\begin{tabular}{|c|c|c|c|}
\hline Strategy ID & Strategy & Category & Reference \\
\hline FOOD & Increase food security & & IPCC (2018) \\
\hline FARM_EDU & Provide specific education to farmers & & IPCC (2018) \\
\hline LIVESTOCK & Support the livestock sector & Agriculture & Gerber et al. (2013b) \\
\hline GMO & Support GMO production & & IPCC (2019) \\
\hline COAL & Support coal extraction & & IPCC (2018) \\
\hline INCINE & Developing incinerators & & European Commission (2001) \\
\hline COMPOST & Support composting waste & & Biala (2011) \\
\hline EN_EFF & Increase energy efficiency & & IPCC (2018) \\
\hline EN_RENEW & Support renewable energies & Energy & IPCC (2018) \\
\hline OIL_DRI & Support oil drilling activities & & IPCC (2018) \\
\hline GAS_DRI & Support gas drilling activities & & IPCC (2018) \\
\hline NUCLEAR & Production and use of nuclear energy & & IPCC (2018) \\
\hline CARB_CAPT & Support carbon capture and storage & & IPCC (2018) \\
\hline DEGROWTH & Transition to degrowth & & Latouche (2010) \\
\hline POLL_TAX & Introduction of a pollution tax (tassa di scopo) & & UN (2015) \\
\hline GREEN_ECO & $\begin{array}{l}\text { Promoting green economy } \\
\text { (e.g., increasing green jobs) }\end{array}$ & & UN (2015) \\
\hline INNO_SUST & $\begin{array}{l}\text { Support technological innovation } \\
\text { for sustainability }\end{array}$ & Industry and economy & UN (2015) \\
\hline TRANSPORT & Support public transports & & IPCC (2018) \\
\hline CIRCULAR & $\begin{array}{l}\text { Transition to circular economy } \\
\text { (reduce, reuse, and recycle) }\end{array}$ & & Circle Economy (2019) \\
\hline PROF_EDU & Training sustainability professionals & & IPCC (2018) \\
\hline TAX_ADV & Reduce tax advantages for polluting companies & & UN (2015) \\
\hline LAND & $\begin{array}{l}\text { Reducing land consumption; } \\
\text { management of parks, forests, and coastal areas }\end{array}$ & $\begin{array}{l}\text { Land planning and } \\
\text { management }\end{array}$ & IPCC (1991) \\
\hline ECO_MIG & Legal recognition of eco-migrants & Migration & $\begin{array}{l}\text { International Organization } \\
\text { for Migration (2008) }\end{array}$ \\
\hline
\end{tabular}


normalized weight below 50\%) were removed and the Louvain method for community detection was applied to detect hyperplanes according to cluster memberships (i.e., groups of deputies sharing multiple policy beliefs, in the case of congruence networks, or strong conflicts, in the case of the conflict networks).

\section{Results and Discussion}

In order to facilitate the interpretation of the results, each political party was attributed to a specific political position, adopting the classical 'left-right' dichotomy. Table 2 illustrates the number of statements expressed by the deputies on climate change, grouped by political party and period of observation. The deputies of the Democratic Party (Partito Democratico) and the Five Star Movement (Movimento 5 Stelle) were prevailing in the climate change debate, covering almost $50 \%$ of the related statements expressed during the Legislature. In particular, two deputies from the Five Star Movement were highly involved in the debate, namely Mirko Busto and Massimo Felice De Rosa (Table 3), who expressed around $15 \%$ of the total mapped statements.

Figures 1 and 2 show the two-mode networks, with deputies represented by circles of different colors (expressing their political affiliation) and strategies represented by pink squares. Green ties indicate positive statements, while red ties refer to negative statements. As illustrated by these figures, deputies concur on several strategies. They strongly agree on the support for renewable energies (EN_RENEW) and the introduction of novel approaches to land management (LAND). The production of energy from renewable sources has exponentially increased in Italy in recent decades (Legambiente, 2015), and Italian politicians seem to recognize the positive effects of supporting renewables in economic and environmental terms. On the other hand, Italy has a history of abandoning its internal and peripheral areas in favor of urbanized areas (Carrosio, 2019), which has therefore led to greater exposure to extreme events (Istituto Superiore per la Protezione e la Ricerca Ambientale, 2018), causing damage and incidents which have attracted public attention. However, a group of right and center-right wing deputies are against the idea of degrowth (DEGROWTH) and generally oppose any economic approach that could harm Italian firms. This strategy was also debated before the ratification of the Paris Agreement when the possibility of new legal restrictions was of concern to the manufacturing sector; after the Paris ratification, it was no longer discussed in the Legislature. Another group, mainly composed of left and center-left wing deputies and deputies from the Five Star Movement, jointly oppose GMO deployment and are advocates for traditional/biological farming methods (GMO). Since the agri-food sector is particularly important to the Italian economy, this strategy takes a lot of space in the public debate, which is divided between the negative opinions regarding GMOs espoused by the main national association of Italian farmers (Coldiretti) and the positive assessment of the scientific community (Pellegrino, Bedini, Nuti, \& Ercoli, 2018). However, the former seems to prevail in the Italian Chamber of Deputies.

Table 2. Participation in climate change debates: Number of statements by political party.

\begin{tabular}{|c|c|c|c|c|c|}
\hline \multirow[b]{2}{*}{ Political party } & \multirow[b]{2}{*}{ Political position } & \multicolumn{2}{|c|}{$\begin{array}{l}\text { Statements } \\
\text { pre-October } 2016\end{array}$} & \multicolumn{2}{|c|}{$\begin{array}{c}\text { Statements } \\
\text { post-October } 2016\end{array}$} \\
\hline & & $\mathrm{N}^{\circ}$ & $\%$ & $\mathrm{~N}^{\circ}$ & $\%$ \\
\hline Alternativa Libera-Possibile & Left & 7 & 2.5 & 2 & 3.1 \\
\hline Articolo 1-Movimento Democratico e Progressista & Left & 1 & 0.4 & 5 & 7.7 \\
\hline Sinistra Ecologia Libertà & Left & 62 & 21.9 & 6 & 9.2 \\
\hline Democrazia Solidale-Centro Democratico & Centre-left & 7 & 2.5 & 1 & 1.5 \\
\hline Partito Democratico & Centre-left & 73 & 25.8 & 14 & 21.5 \\
\hline $\begin{array}{l}\text { Partito Socialista Italiano-Liberali per I'Italia } \\
\quad \text {-Indipendenti }\end{array}$ & Centre-left & 5 & 1.8 & 1 & 1.5 \\
\hline Alternativa Popolare-Centristi per l'Europa-NCD & Centre & 13 & 4.6 & 0 & 0.0 \\
\hline Civici e Innovatori & Centre & 7 & 2.5 & 2 & 3.1 \\
\hline Misto-Minoranze linguistiche & Centre & 1 & 0.4 & 0 & 0.0 \\
\hline Misto-Nessuna componente & Centre & 2 & 0.7 & 1 & 1.5 \\
\hline Scelta Civica per l’Italia & Centre & 2 & 0.7 & 3 & 4.6 \\
\hline Movimento 5 Stelle & Protest party & 62 & 21.9 & 18 & 27.7 \\
\hline Alleanza Liberalpopolare-Autonomie & Centre-right & 2 & 0.7 & 0 & 0.0 \\
\hline Forza Italia_II Popolo della Libertà & Centre-right & 12 & 4.2 & 3 & 4.6 \\
\hline Fratelli d'Italia-Alleanza Nazionale & Right & 2 & 0.7 & 3 & 4.6 \\
\hline Lega Nord & Right & 20 & 7.1 & 1 & 1.5 \\
\hline Government/Speaker of the Chamber of Deputies & No political position & 5 & 1.8 & 5 & 7.7 \\
\hline Total & & 283 & 100.0 & 65 & 100.0 \\
\hline
\end{tabular}


Table 3. Ten most active deputies on climate change debates.

Statements

Deputy

Political party

Political position

pre-October $2016\left(\mathrm{~N}^{\circ}\right)$

Mirko Busto

Movimento 5 Stelle

Stella Bianchi

Partito Democratico

Serena Pellegrino

Sinistra Ecologia Libertà

Movimento 5 Stelle

Filiberto Zaratti

Sinistra Ecologia Libertà

Partito Democratico

Protest party

20

Centre-left 20

Chiara Braga

Adriano Zaccagnini

Sinistra Ecologia Libertà

Left

17

Protest party $\quad 15$

Left 14

Centre-left 9

Susanna Cenni

Partito Democratico

Samuele Segoni

Alternativa Libera-Possibile

Left

Centre-left

Left

8

Salvatore Matarrese

Civici e Innovatori

Centre

8

7

6

Deputy

Political party

Political position

Statements

Mirko Busto

Movimento 5 Stelle

Enrico Borghi

Massimo Felice De Rosa

Partito Democratico

Movimento 5 Stelle

Sinistra Ecologia Libertà

Serena Pellegrino

Adriano Zaccagnini

Ermete Realacci

Gian Luca Galletti

Sinistra Ecologia Libertà

Partito Democratico

Goverment

Alleanza Liberalpopolare-Autonomie

Alternativa Libera-Possibile

Samuele Segoni

Fratelli d'Italia-Alleanza Nazionale

$\begin{array}{ll}\text { Protest party } & 7 \\ \text { Centre-left } & 5 \\ \text { Protest party } & 3 \\ \text { Left } & 3 \\ \text { Left } & 2 \\ \text { Centre-left } & 2 \\ \text { Centre-right } & 2 \\ \text { Left } & 2 \\ \text { Right } & 2 \\ \end{array}$

Two strategies emerge as highly divisive: the support for oil drilling activities (OIL_DRI) and the legal recognition of eco-migrants (ECO_MIG). While the first concerns the opposition of left-wing deputies and deputies from the Five Star Movement to the energy policy of the Italian Government, which envisaged the exploration of new oil deposits for reducing Italy's dependence on imported energy supplies, the latter is mainly a left-wing/right-wing

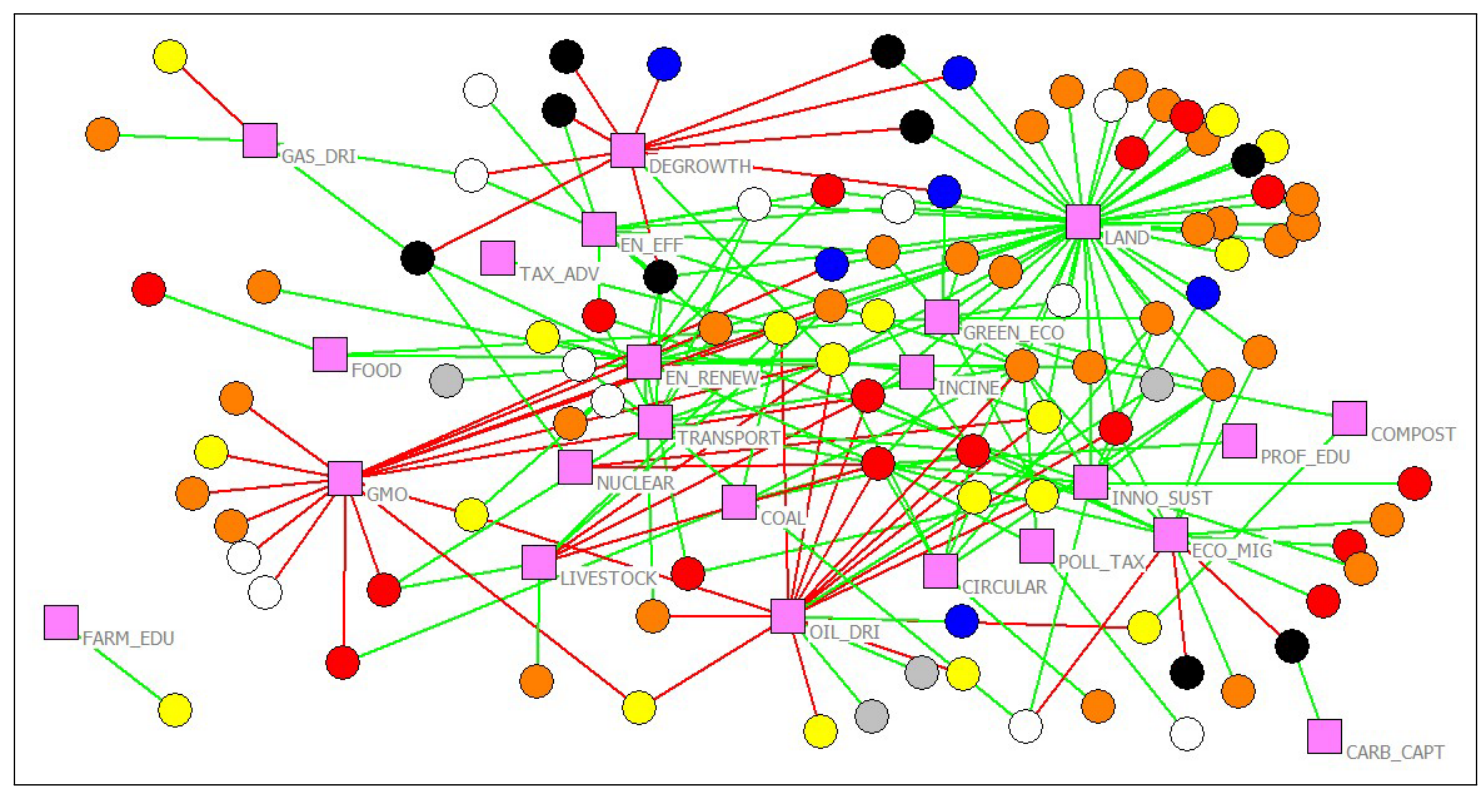

Figure 1. Pre-October 2016 two-mode network. Notes: Pink squares = debated strategies; red circles = left parties' deputies; orange circles = center-left parties' deputies; white circles = center parties' deputies; yellow circles = protest parties' deputies; blue circles = center-right parties' deputies; black circles = right parties' deputies; grey circles = members of the Government/Speaker of the Chamber of Deputies. Green ties indicate that policymakers agree on certain strategies; red ties indicate their disagreement. 


\section{COGITATIO}

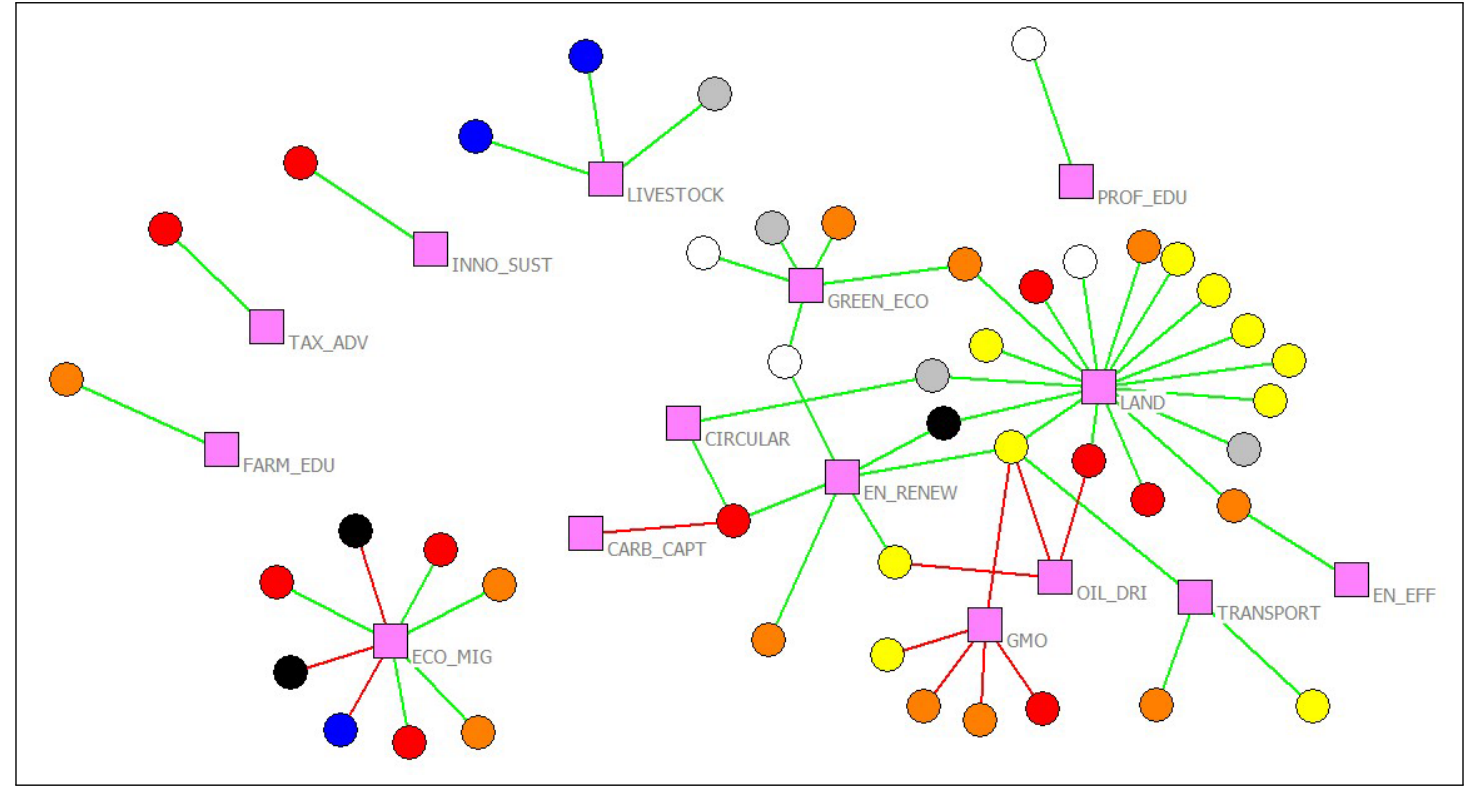

Figure 2. Post-October 2016 two-mode network. Notes: Pink squares = debated strategies; red circles = left parties' deputies; orange circles = center-left parties' deputies; white circles = center parties' deputies; yellow circles = protest parties' deputies; blue circles = center-right parties' deputies; black circles = right parties' deputies; grey circles = members of the Government/Speaker of the Chamber of Deputies. Green ties indicate that policymakers agree on certain strategies; red ties indicate their disagreement.

conflict. Yet, this is probably the only strategy where there is a clear distinction between the two opposing sides of the political arena, which are unable to find a solution for this issue.

Figures 3-6 show the one-mode networks that were created from the two-mode networks (Figures 1 and 2).
These figures illustrate more clearly the presence of discourse coalitions and conflict between Italian deputies. In the pre-ratification period of the Paris Agreement (Figures 3 and 5), a central cloud of policymakers emerged who shared several policy beliefs, from different political parties, in the congruence network; how-

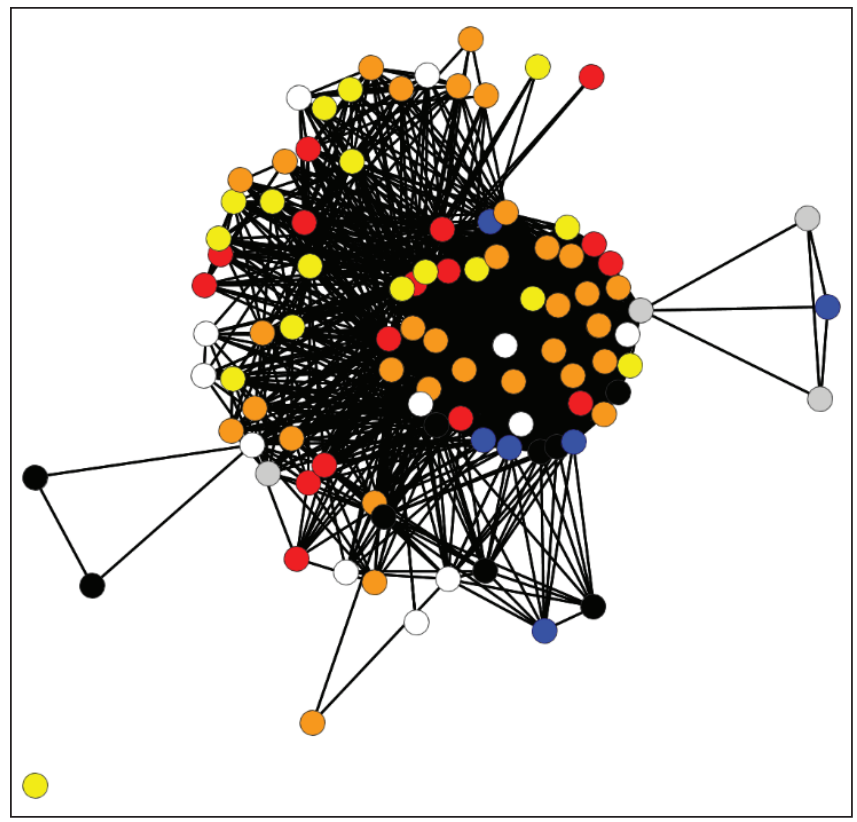

(a)

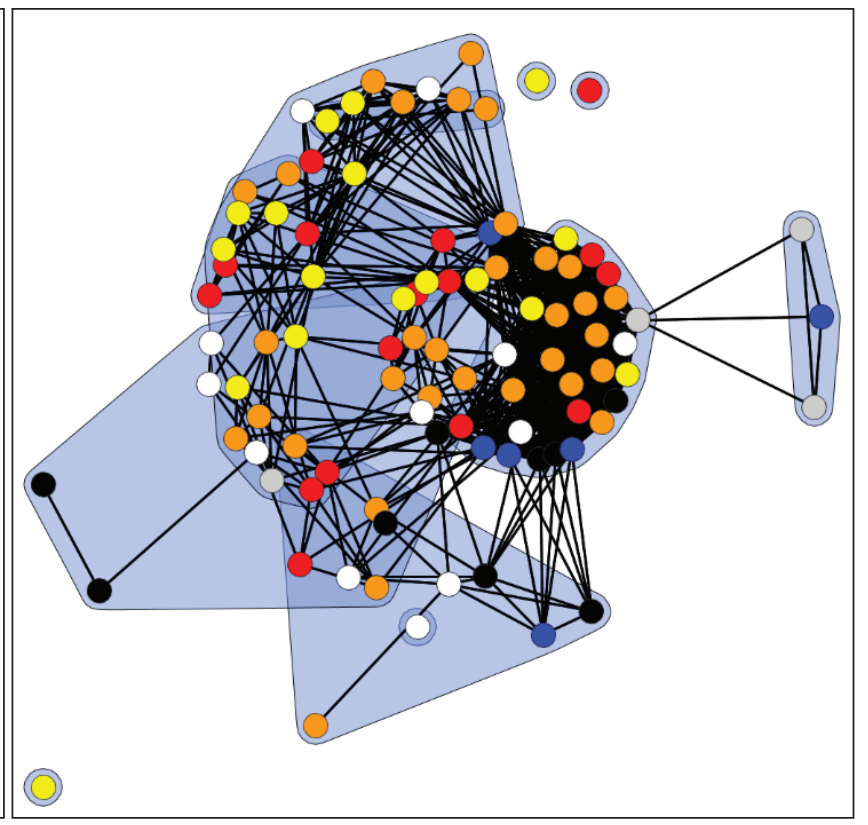

(b)

Figure 3. Pre-October 2016 congruent one-mode networks. (a) Total. (b) Threshold+hyperplanes. Notes: Red circles = left parties' deputies; orange circles = center-left parties' deputies; white circles = center parties' deputies; yellow circles = protest parties' deputies; blue circles = center-right parties' deputies; black circles = right parties' deputies; grey circles $=$ members of the Government/Speaker of the Chamber of Deputies. 


\section{COGITATIO}

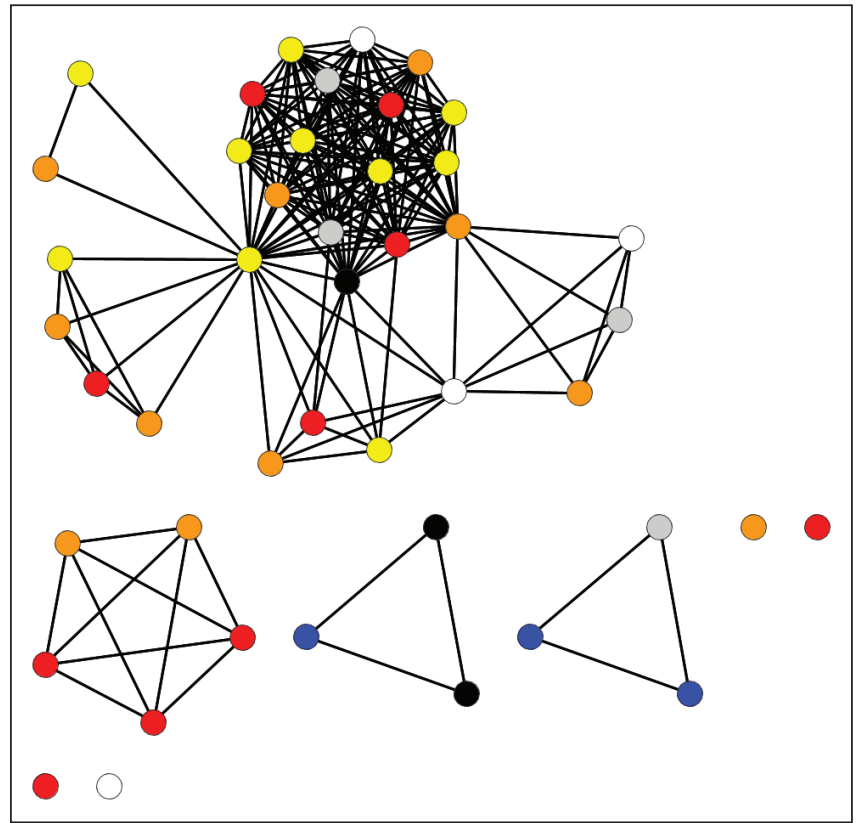

(a)

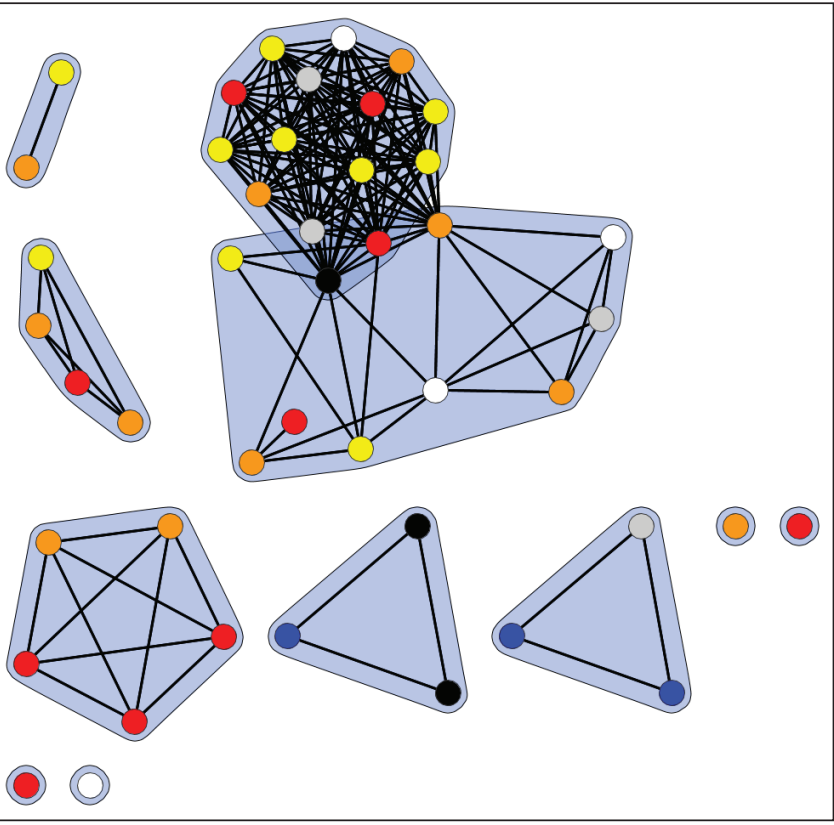

(b)

Figure 4. Post-October 2016 congruent one-mode networks. (a) Total. (b) Threshold+hyperplanes. Notes: Red circles = left parties' deputies; orange circles = center-left parties' deputies; white circles = center parties' deputies; yellow circles = protest parties' deputies; blue circles = center-right parties' deputies; black circles = right parties' deputies; grey circles $=$ members of the Government/Speaker of the Chamber of Deputies.

ever, by looking at Figure 3b, deputies from the centerleft parties (orange nodes) are predominant in this cloud, sharing strong linkages. The conflict network (Figure 5) shows that disputes arise from deputies with different political positions, as expected; there is only one exception, a deputy from a center-left party that does not agree on a strategy supported by colleagues (see the top left hyperplane in Figure $5 b$ ). However, it is inter-

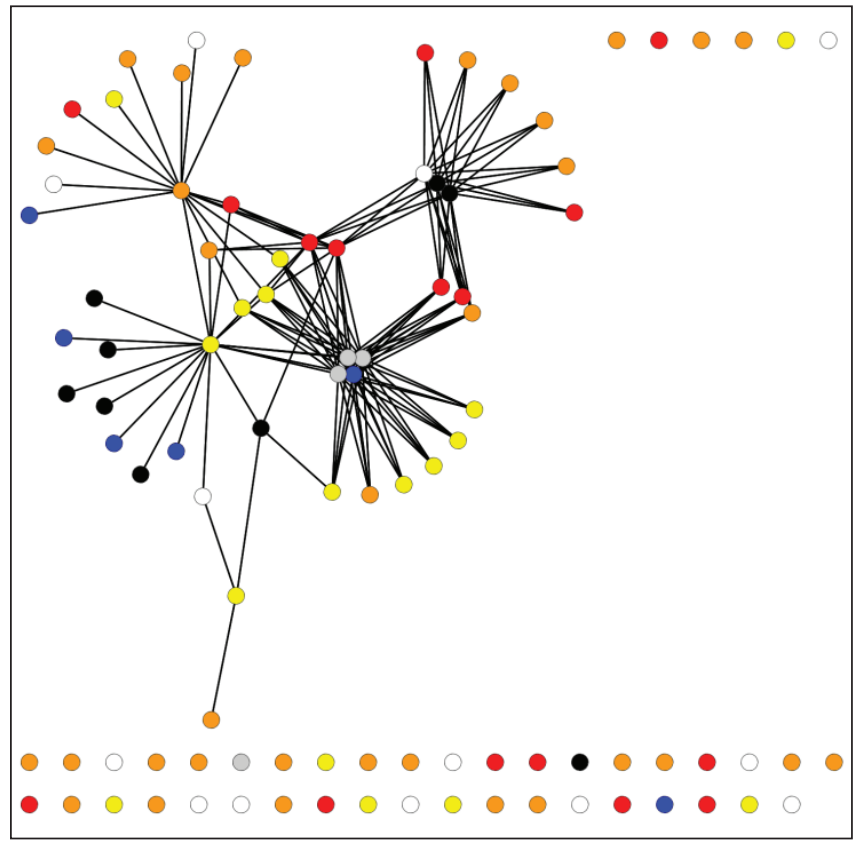

(a)

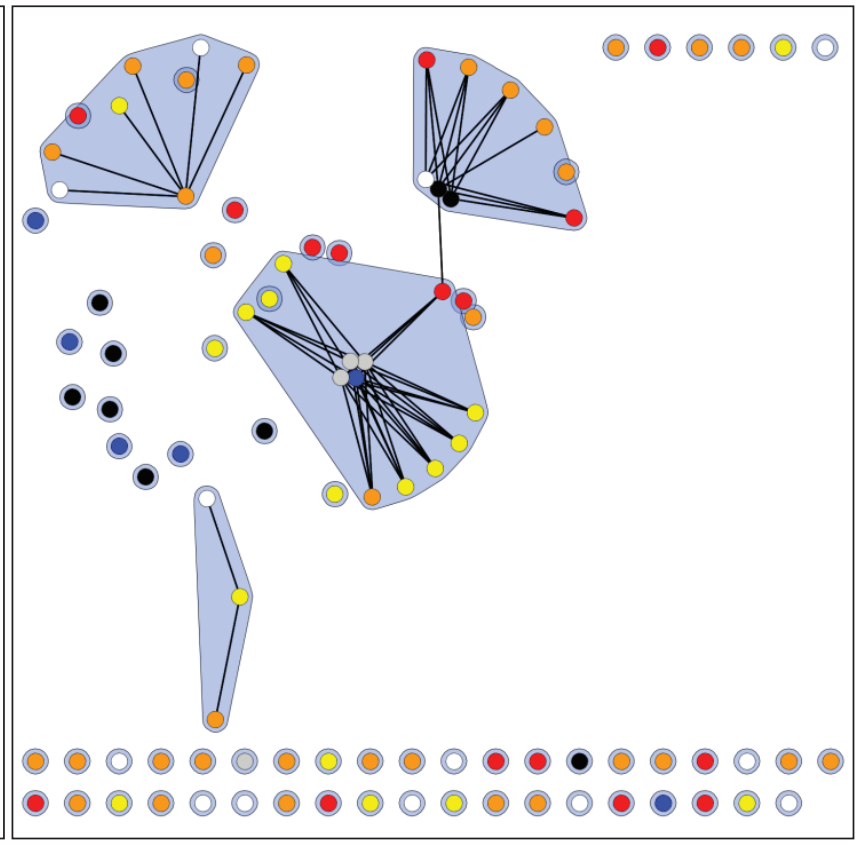

(b)

Figure 5. Pre-October 2016 conflict one-mode networks. (a) Total. (b) Threshold+hyperplanes. Notes: Red circles = left parties' deputies; orange circles = center-left parties' deputies; white circles = center parties' deputies; yellow circles = protest parties' deputies; blue circles = center-right parties' deputies; black circles = right parties' deputies; grey circles $=$ members of the Government/Speaker of the Chamber of Deputies. 


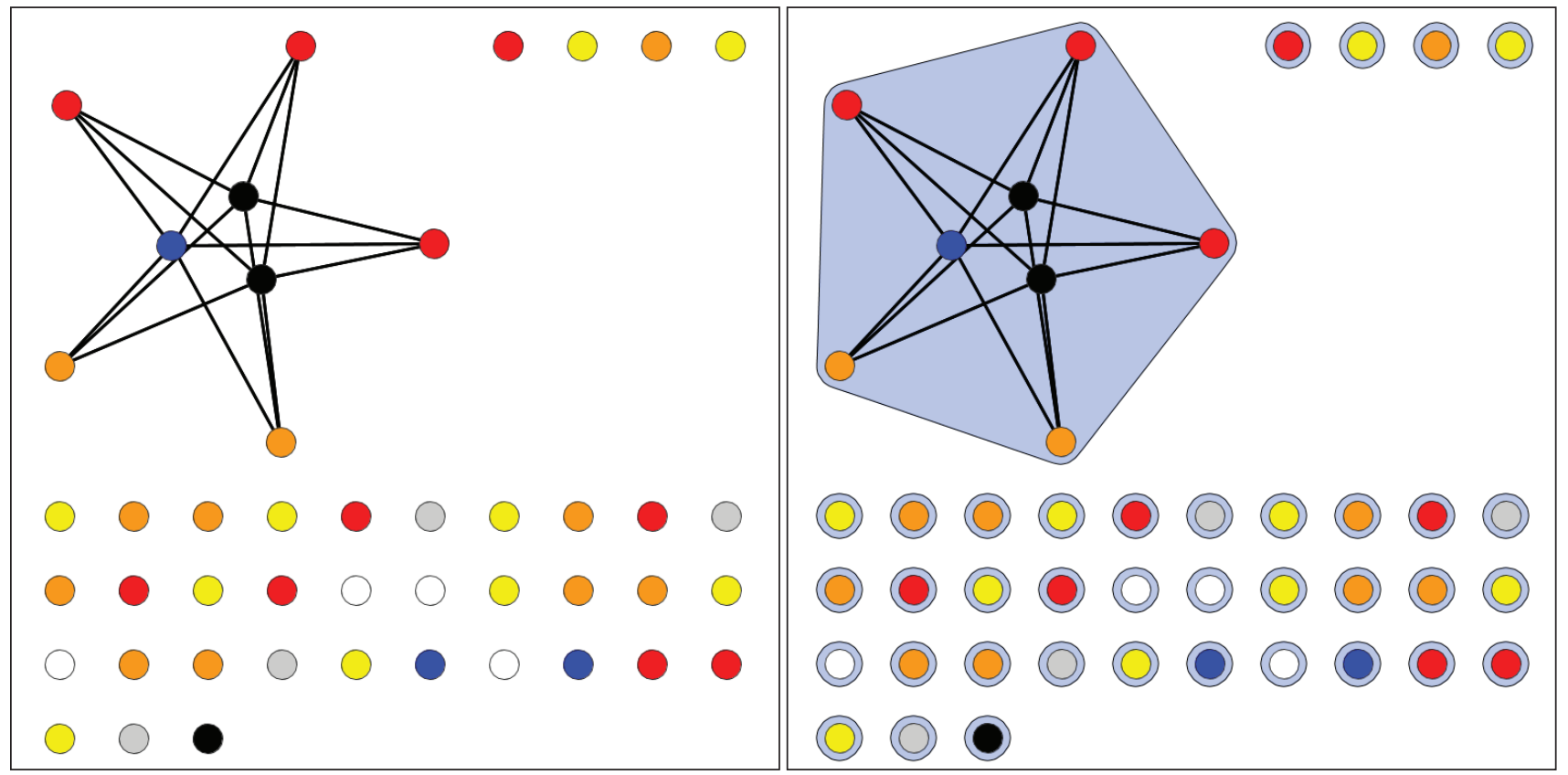

(a)

(b)

Figure 6. Post-October 2016 conflict one-mode networks. (a) Total. (b) Threshold+hyperplanes. Notes: Red circles = left parties' deputies; orange circles = center-left parties' deputies; white circles = center parties' deputies; yellow circles = protest parties' deputies; blue circles = center-right parties' deputies; black circles = right parties' deputies; grey circles $=$ members of the Government/Speaker of the Chamber of Deputies.

esting to note that the Five Star Movement is always involved in emerging conflicts, trying to legitimate its role as a protest party. Regarding the post-ratification period (Figures 4 and 6), networks appear much polarized. In the congruence network (Figure 4), the classical 'leftright' dichotomy is more pronounced, while the Five Star Movement loses its protesting nature: in particular, deputies from center-right and right parties support certain strategies, which are not discussed by other deputies (supporting the livestock sector, LIVESTOCK; see Figure 2) or even contrasted by center-left and left parties (the eco-migrants issue, ECO_MIG; see Figure 2). Indeed, this conflict on the legal recognition of eco-migrants is pretty much evident in Figure 6, as it is the only strategy where left/center-left and right/center-right parties do not strongly agree. Coalitions arising from congruence networks can be analyzed according to the political homophily literature. Political homophily occurs when actors with similar political characteristics express similar policy beliefs (Gerber, Henry, \& Lubell, 2013a). The ho- mophily between political groups (in our case, political parties sharing the same political position; see Table 2) is measured using the Krackhardt and Stern's (1988) E-I index, which allows one to understand if a group is more externally or internally oriented, in terms of their shared beliefs. This index ranges between -1 and 1 : Scores close to -1 indicate that deputies agree only with those who share the same political position; scores close to 0 show that deputies share similar beliefs equally with those who have the same political position and those who do not; scores close to 1 suggest a tendency to share policy beliefs with deputies who have different political positions. We estimate the E-I index by focusing on the congruence networks pre- and post-October 2016 (Table 4); we do not concentrate on the conflict networks because deputies with similar political positions rarely disagree with one another (except for the centerleft deputy discussed above; see Figure 5b), i.e., the $\mathrm{E}-\mathrm{I}$ index would have been biased. In general, we do not detect high levels of political homophily, since E-I indexes

Table 4. E-I index.

\begin{tabular}{lll}
\hline Political position & E-I index pre-October 2016 & E-I index post-October 2016 \\
\hline Left & 0.619 & 0.662 \\
Centre-left & 0.260 & 0.696 \\
Centre & 0.762 & 0.862 \\
Protest party & 0.530 & 0.284 \\
Centre-right & 0.852 & 0.333 \\
Right & 0.708 & 0.833 \\
No political position & 0.826 & 0.897 \\
\hline
\end{tabular}


are often in between 0.500 and 1 , which means that deputies share similar policy beliefs with those who have different political positions. In the pre-October 2016 period, the center-right group shows the higher E-I index while the center-left group has an index close to zero. After the ratification of the Paris Agreement, the centerright group's index dropped to 0.333 , while almost all other groups increased their indexes, which indicates that Italian parties had become more collaborative during this period. Moreover, the E-I indexes showed by the Five Star Movement (protest party) indicate that this party was not totally open to supporting the strategies shared by other parties, nor was it totally withdrawn, despite its conflict over several topics with others.

These results suggest that members of the centerleft governing parties (Partito Democratico, Partito Socialista Italiano-Liberali per I'Italia-Indipendenti, Democrazia Solidale-Centro Democratico, and other parties who supported the three Governments of the Legislature) formed a more cohesive group during the period before the Paris Agreement ratification. In contrast, the Movimento 5 Stelle alternated between having shared policy beliefs and strong political conflict with the other parties.

\section{Conclusions}

This work contributes to the growing body of knowledge on climate change policymaking, providing empirical evidence on the Italian case study. It applies DNA to investigate the political debate on climate change by the Italian Chamber of Deputies. Our analysis suggests that, consistent with previous studies on European countries (e.g., Hess \& Renner, 2019; Little, 2017; Marcinkiewicz \& Tosun, 2015), climate change is an issue where rival political parties can have convergent policy beliefs. This is reflected also in the declarations expressed by the Italian deputies: most of them have stated their total support to the Paris Agreement, with only the deputies of the Lega Nord party abstaining from the final vote.

However, some divisive strategies were identified among political parties related to climate change. Since Italian policymakers generally accept the evidence of climate change (only one deputy has denied the existence of a correlation between human activities and climate change: Paolo Tancredi, from Alternativa PopolareCentristi per l'Europa-NCD), situations of conflict arise when the debate focuses on the strategies to cope with this problem. Deputies from the left and center-left parties and the Five Star Movement were predominant in the political debate, creating persistent coalitions over time around certain core strategies that were also supported by other policymakers (e.g., reduction of land consumption and management of green areas, and support for renewable energies). However, despite the absence of strong conflicts, a small-scale polarization is visible in the Italian political arena, which is more evident when the debate switches to sensitive topics such as im- migration and the economy (for example, oil drilling activities). Shifting to a more pro-active attitude towards climate change adaptation actions has fostered new debates in Italy, modifying the positioning of policymakers and supporting the creation of both new alliances and divisions according to the topic. This polarized debate that we identified with DNA in the case of oil drilling could not only be related to previous case study evidence from Australia on polarized discourses around environmental conflict (Lucas \& Warman, 2018) but also to the application of discourse analysis to distinguish between competing coalitions and their shared narratives in the UK fracking debate (Bomberg, 2017), as well as to the application of discursive boundary work to study the dynamics of discourse coalitions in the US fracking debate (Metze \& Dodge, 2016).

In sum, our study's empirical contribution is thus to employ DNA to the Italian climate change political debate, highlighting that political conflicts are driven by political strategies to cope with climate change. Furthermore, the complexities that we have empirically identified as part of this debate (including the concurrence on distinct strategies) suggest that a conceptual simplification of viewing the environmental policy processes as consisting of sequential or cyclical phases of governmental problem-solving (e.g., Burton, 2006) is probably less appropriate, in line with Howlett et al.'s (2017) call for more complex conceptual models that enable us to better understand competing coalitions of interests within a policy subsystem.

Nevertheless, this study faces two main limitations. First, we have no information on the Senators' statements. The Italian Parliament consists of the Chamber of Deputies and the Senate, but the verbatim reports from the senators include collective statements. Therefore, we could not distinguish which senator had pronounced a specific policy belief, while assigning one policy belief to multiple senators could bias the analysis. Second, we were not able to investigate the linkage between deputies' statements and the actual implementation of climate change-related strategies. Further analysis should be dedicated to investigating the influence of environmental advocacy coalitions for implementing dedicated policies.

\section{Acknowledgments}

We would like to thank the two anonymous reviewers as well as the Academic Editor of this thematic issue (Professor Philip Leifeld) for their helpful comments. We also gratefully acknowledge our colleagues from the Department of Economics and Management, University of Helsinki, for the fruitful discussions about climate change.

\section{Conflict of Interests}

The authors declare no conflict of interests. 


\section{References}

Bang, G., Hovi, J., \& Skodvin, T. (2016). The Paris agreement: Short-term and long-term effectiveness. Politics and Governance, 4(3), 209-218. https://doi.org/ 10.17645/pag.v4i3.640

Biala, J. (2011). The benefits of using compost for mitigating climate change (Technical report). Sydney: New South Wales Office of Environment and Heritage. https://doi.org/10.13140/RG.2.1.1547.1126

Biesbroek, G. R., Swart, R. J., Carter, T. R., Cowan, C., Henrichs, T., Mela, H., . . . Rey, D. (2010). Europe adapts to climate change: Comparing national adaptation strategies. Global Environmental Change, 20(3), 440-450. https://doi.org/10.1016/ j.gloenvcha.2010.03.005

Biscotti, A. M., \& D'Amico, E. (2016). What are political leaders' environmental intentions? The impact of social identification processes and macro-economic conditions. Ecological Economics, 129, 152-160. https://doi.org/10.1016/j.ecolecon.2016.06.004

Bomberg, E. (2017). Shale we drill? Discourse dynamics in UK fracking debates. Journal of Environmental Policy \& Planning, 19(1), 72-88. https://doi.org/ 10.1080/1523908X.2015.1053111

Borgatti, S. P., Everett, M. G., \& Freeman, L. C. (2002). Ucinet for Windows: Software for social network analysis. Harvard, MA: Analytic Technologies.

Burton, P. (2006). Modernising the policy process: Making policy research more significant? Policy Studies, 27(3), 172-192. https://doi.org/10.1080/ 01442870600885974

Carbone, M. (2009). Italy in the European Union, between Prodi and Berlusconi. The International Spectator, 44(3), 97-115. https://doi.org/10.1080/ 03932720903148914

Carrosio, G. (2019). I margini al centro. L'Italia delle aree interne tra fragilità e innovazione [Marginal areas. Italian disadvantaged zones between fragility and innovation]. Rome: Donzelli Editore.

Carter, N., Ladrech, R., \& Little, C. (2014). Political parties' climate policies in the UK, Italy and Denmark. Paper presented at the ECPR General Conference 2014, Glasgow. Retrieved from https://ecpr.eu/ Filestore/PaperProposal/f51e32ac-9212-4623-813f2fc6a4040668.pdf

Circle Economy. (2019). The circularity gap report 2019. Amsterdam: Circle Economy. Retrieved from https://docs.wixstatic.com/ugd/ad6e59_ba1e4d16c 64f44fa94fbd8708eae8e34.pdf

De Blasio, E., \& Sorice, M. (2013). The framing of climate change in Italian politics and its impact on public opinion. International Journal of Media \& Cultural Politics, 9(1), 59-69. https://doi.org/10.1386/macp.9.1.59_1

De Gregorio Hurtado, S., Olazabal, M., Salvia, M., Pietrapertosa, F., Feliú, E., Olazabal, E., . . . Reckien, D. (2014). Multilevel climate governance and urban climate action. In R. Dawson, A. Wyckmans, O. Heidrich, J. Köh- ler, S. Dobson, \& E. Feliu (Eds.), Understanding cities: Advances in integrated assessment of urban sustainability (pp. 77-88). Newcastle: Centre for Earth Systems Engineering Research (CESER).

Diffenbaugh, N. S., Singh, D., Mankin, J. S., Horton, D. E., Swain, D. L., Touma, D., . . Rajaratnam, B. (2017). Quantifying the influence of global warming on unprecedented extreme climate events. Proceedings of the National Academy of Sciences of the United States of America, 114(19), 4881-4886. https://doi. org/10.1073/pnas.1618082114

Dunlap, R. E., \& McCright, A. M. (2011). Organized climate change denial. In J. S. Dryzek, R. B. Norgaard, \& D. Schlosberg (Eds.), The Oxford handbook of climate change and society (pp. 144-160). Oxford: Oxford University Press. https://doi.org/10.1093/oxfordhb/ 9780199566600.003.0010

European Commission. (2001). Waste management options and climate change. Luxembourg: Office for Official Publications of the European Communities.

European Investment Bank. (2019). EIB climate survey. European Investment Bank. Retrieved from https://www.eib.org/en/surveys/2nd-citizensurvey/index.htm

Fergie, G., Leifeld, P., Hawkins, B., \& Hilton, S. (2019). Mapping discourse coalitions in the minimum unit pricing for alcohol debate: A discourse network analysis of UK newspaper coverage. Addiction, 114(4), 741-753. https://doi.org/10.1111/add.14514

Fisher, D. R., \& Leifeld, P. (2019). The polycentricity of climate policy blockage. Climatic Change, 155(4), 469-487. https://doi.org/10.1007/s10584019-02481-y

Fisher, D. R., Leifeld, P., \& Iwaki, Y. (2013). Mapping the ideological networks of American climate politics. Climatic Change, 116(3/4), 523-545. https://doi.org/ 10.1007/s10584-012-0512-7

Gerber, E. R., Henry, A. D., \& Lubell, M. (2013a). Political homophily and collaboration in regional planning networks. American Journal of Political Science, 57(3), 598-610. https://doi.org/10.1111/ajps.12011

Gerber, P. J., Steinfeld, H., Henderson, B., Mottet, A., Opio, C., Dijkman, J., . . . Tempio, G. (2013b). Tackling climate change through livestock: A global assessment of emissions and mitigation opportunities. Rome: Food and Agriculture Organization of the United Nations.

Ghinoi, S., Wesz, V. J., Jr., \& Piras, S. (2018). Political debates and agricultural policies: Discourse coalitions behind the creation of Brazil's Pronaf. Land Use Policy, 76, 68-80. https://doi.org/10.1016/j.landusepol. 2018.04.039

Gupta, J. (2010). A history of international climate change policy. Wiley Interdisciplinary Reviews: Climate Change, 1(5), 636-653. https://doi.org/ 10.1002/wcc.67

Haukkala, T. (2018). A struggle for change: The formation of a green-transition advocacy coalition in Finland. 
Environmental Innovation and Societal Transitions, 27, 146-156. https://doi.org/10.1016/j.eist.2017.12. 001

Hess, D. J. (2014). Sustainability transitions: A political coalition perspective. Research Policy, 43(2), 278-283. https://doi.org/10.1016/j.respol.2013.10.008

Hess, D. J., \& Renner, M. (2019). Conservative political parties and energy transitions in Europe: Opposition to climate mitigation policies. Renewable and Sustainable Energy Reviews, 104, 419-428. https://doi. org/10.1016/j.rser.2019.01.019

Howlett, M., McConnell, A., \& Perl, A. (2017). Moving policy theory forward: Connecting multiple stream and advocacy coalition frameworks to policy cycle models of analysis. Australian Journal of Public Administration, 76(1), 65-79. https://doi.org/10.1111/14678500.12191

Intergovernmental Panel on Climate Change. (1991). Climate change: The IPCC response strategies. Washington, DC: Island Press.

Intergovernmental Panel on Climate Change. (2018). Summary for policymakers. In V. Masson-Delmotte, P. Zhai, H.-O. Pörtner, D. Roberts, J. Skea, P. R. Shukla, ... T. Waterfield (Eds.), Global Warming of $1.5^{\circ} \mathrm{C}$ (pp. 1-24). Geneva: World Meteorological Organization.

Intergovernmental Panel on Climate Change. (2019). Climate change and land: An IPCC special report on climate change, desertification, land degradation, sustainable land management, food security, and greenhouse gas fluxes in terrestrial ecosystems. Geneva: World Meteorological Organization. Retrieved from https://www.ipcc.ch/srccl-report-download-page

International Organization for Migration. (2008). Migration and climate change (IOM Migration Research Series No. 31). Grand-Saconnex: International Organization for Migration.

Istituto Superiore per la Protezione e la Ricerca Ambientale. (2018). Variazioni della temperatura in Italia: Estensione della base dati e aggiornamento della metodologia di calcolo [Temperature variations over Italy: Database extension and update of the calculation methodology]. Rome: ISPRA.

Keohane, R. O., \& Oppenheimer, M. (2016). Paris: Beyond the climate dead end through pledge and review? Politics and Governance, 4(3), 142-151. https://doi.org/10.17645/pag.v4i3.634

Krackhardt, D., \& Stern, R. N. (1988). Informal networks and organizational crises: An experimental simulation. Social Psychology Quarterly, 51(2), 123-140. https://doi.org/10.2307/2786835

Kukkonen, A., Ylä-Anttila, T., \& Broadbent, J. (2017). Advocacy coalitions, beliefs and climate change policy in the United States. Public Administration, 95(3), 713-729. https://doi.org/10.1111/padm.12321

Kukkonen, A., Ylä-Anttila, T., Swarnakar, P., Broadbent, J., Lahsen, M., \& Stoddart, M. C. J. (2018). International organizations, advocacy coalitions, and domestication of global norms: Debates on climate change in
Canada, the US, Brazil, and India. Environmental Science and Policy, 81, 54-62. https://doi.org/10.1016/ j.envsci.2017.12.008

Lanzone, L., \& Woods, D. (2015). Riding the populist web: Contextualizing the Five Star Movement (M5S) in Italy. Politics and Governance, 3(2), 54-64. https:// doi.org/10.17645/pag.v3i2.246

Latouche, S. (2010). Degrowth. Journal of Cleaner Production, 18(6), 519-522. https://doi.org/10.1016/ j.jclepro.2010.02.003

Legambiente. (2015). Comuni Rinnovabili 2015 [Renewable municipalities 2015]. Rome: Legambiente. Retrieved from http://www.comunirinnovabili.it/ wp-content/uploads/2015/05/Comuni-Rinnovabili2015_def.pdf

Leifeld, P. (2010). Discourse network analyzer (DNA) manual. Retrieved from https://github.com/leifeld/ dna

Leifeld, P. (2017). Discourse network analysis: Policy debates as dynamic networks. In J. N. Victor, A. H. Montgomery, \& M. N. Lubbell (Eds.), The Oxford handbook of political networks (pp. 301-325). Oxford: Oxford University Press.

Leifeld, P., \& Brandenberger, L. (2019). Endogenous coalition formation in policy debates. arXiv.org. Retrieved from https://arxiv.org/abs/1904.05327

Leifeld, P., \& Haunss, S. (2012). Political discourse networks and the conflict over software patents in Europe. European Journal of Political Research, 51(3), 382-409. https://doi.org/10.1111/j.14756765.2011.02003.x

Little, C. (2017). Portrait of a laggard? Environmental politics and the Irish general election of February 2016. Environmental Politics, 26(1), 183-188. https://doi. org/10.1080/09644016.2016.1248617

Locchi, M. C. (2014). The Mediterranean Sea as a European border: Trans-Mediterranean migration, forced return and violation of fundamental rights. In E. Vallet (Ed.), Borders, fences and walls: State of insecurity? (pp. 11-25). Surrey: Ashgate Publishing.

Lucas, C., \& Warman, R. (2018). Disrupting polarized discourses: Can we get out of the ruts of environmental conflicts? Environment and Planning C: Politics and Space, 36(6), 987-1005. https://doi.org/ $10.1177 / 2399654418772843$

Marchetti, A. (1996). Climate change politics in Italy. In T. O'Riordan \& J. Jäger (Eds.), Politics of climate change: A European perspective (pp. 298-329). London: Routledge.

Marcinkiewicz, K., \& Tosun, J. (2015). Contesting climate change: Mapping the political debate in Poland. East European Politics, 31(2), 187-207. https://doi.org/ 10.1080/21599165.2015.1022648

Metze, T., \& Dodge, J. (2016). Dynamic discourse coalitions on hydro-fracking in Europe and the United States. Environmental Communication, 10(3), 365-379. https://doi.org/10.1080/17524032.2015. 1133437 
Mukherjee, I., \& Howlett, M. (2015). Who is a stream? Epistemic communities, instrument constituencies and advocacy coalitions in public policy-making. Politics and Governance, 3(2), 65-75. https://doi.org/ 10.17645/pag.v3i2.290

Nagel, M., \& Satoh, K. (2019). Protesting iconic megaprojects: A discourse network analysis of the evolution of the conflict over Stuttgart 21. Urban Studies, 56(8), 1681-1700. https://doi.org/10.1177/ 0042098018775903

Oppermann, K., Kaarbo, J., \& Brummer, K. (2017). Introduction: Coalition politics and foreign policy. European Political Science, 16, 457-462. https://doi.org/ 10.1057/s41304-016-0064-9

Pasimeni, M. R., Valente, D., Zurlini, G., \& Petrosillo, I. (2019). The interplay between urban mitigation and adaptation strategies to face climate change in two European countries. Environmental Science and Policy, 95, 20-27. https://doi.org/10.1016/j.envsci. 2019.02.002

Pasquaré, F. A., \& Oppizzi, P. (2012). How do the media affect public perception of climate change and geohazards? An Italian case study. Global and Planetary Change, 90, 152-157. https://doi.org/10.1016/ j.gloplacha.2011.05.010

Pearce, W., Brown, B., Nerlich, B., \& Koteyko, N. (2015). Communicating climate change: Conduits, content, and consensus. Wiley Interdisciplinary Reviews: Climate Change, 6(6), 613-626. https://doi.org/ 10.1002/wcc.366

Pellegrino, E., Bedini, S., Nuti, M., \& Ercoli, L. (2018). Impact of genetically engineered maize on agronomic, environmental and toxicological traits: A meta-analysis of 21 years of field data. Scientific Reports, 8(1), 3113. https://doi.org/10.1038/s41598018-21284-2

Rossen, I. L., Dunlop, P. D., \& Lawrence, C. M. (2015). The desire to maintain the social order and the right to economic freedom: Two distinct moral pathways to climate change scepticism. Journal of Environmental Psychology, 42, 42-47. https://doi.org/10.1016/ j.jenvp.2015.01.006

Sabatier, P. A. (1991). Toward better theories of the policy process. PS: Political Science \& Politics, 24(2), 147-156. https://doi.org/10.2307/419923

Sartori, N. (2016). La politica energetica [The energy policy]. In E. Greco \& N. Ronzitti (Eds.), Rapporto sulla politica estera italiana: Il governo Renzi [Report on the Italian foreign policy: The Renzi government] (pp. 65-70). Roma: Edizioni Nuova Cultura.

Schmidt, V. A. (2008). Discursive institutionalism: The explanatory power of ideas and discourse. Annual Review of Political Science, 11, 303-326. https://doi. org/10.1146/annurev.polisci.11.060606.135342

UN. (2015). Transforming our world: The 2030 agenda for sustainable development. Resolution adopted by the General Assembly of the United Nations on 25 September 2015. New York, NY: UN. Retrieved from https://www.un.org/ga/search/view_doc.asp? symbol=A/RES/70/1\&Lang $=E$

Victor, D. G. (2016). What the framework convention on climate change teaches us about cooperation on climate change. Politics and Governance, 4(3), 133-141. https://doi.org/10.17645/pag.v4i3.657

Wallaschek, S. (2019). The discursive construction of solidarity: Analysing public claims in Europe's migration crisis. Political Studies, 68(1), 74-92. https://doi.org/ $10.1177 / 0032321719831585$

Wendler, F. (2019). The European Parliament as an arena and agent in the politics of climate change: Comparing the external and internal dimension. Politics and Governance, 7(3), 327-338. https://doi.org/ 10.17645/pag.v7i3.2156

Westerhoff, L. (2010). 'Planning for today': The nature and emergence of adaptation measures in Italy. In E. C. H. Keskitalo (Ed.), Developing adaptation policy and practice in Europe: Multi-level governance of climate change (pp. 233-270). Berlin: Springer.

\section{About the Authors}

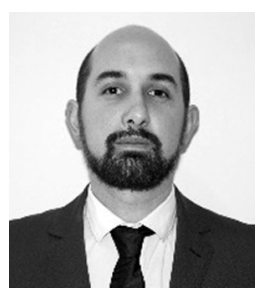

Stefano Ghinoi is a Post-Doc Researcher at the Department of Economics and Management, University of Helsinki. His research interests focus on innovation, sustainability, and policy evaluation. He uses Social Network Analysis, quantitative statistical methods, and combinations of qualitative and quantitative approaches for investigating topics related to the circular economy, firm innovativeness and internationalization, climate change, and local development.

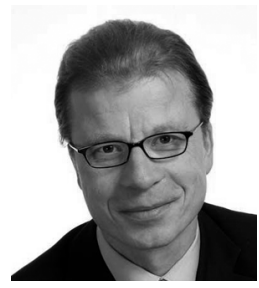

Bodo Steiner is a Professor in Food Economics and Business Management at the Department of Economics and Management, University of Helsinki. He earned a PhD from the University of Reading and has previously held faculty and visiting appointments at the University of California-Berkeley, University of Alberta, University College Cork, University of Southern Denmark, University of Kiel, and Beijing Normal University. His research and teaching interests focus on organizational sustainability, in particular, social sustainability in food systems, value chains, and organizational innovations. 